\title{
Placental transfer and maternal and fetal hemodynamic effects of ketanserin in the pregnant ewe
}

\author{
Tom J. Schneider*, Piet C. Struijk, Fred K. Lotgering, Henk C.S. Wallenburg \\ Department of Obstetrics and Gynecology, EE 2283, School of Medicine and Health Sciences, Erasmus University, P.O. Box 1738, 3000 DR \\ Rotterdam, The Netherlands
}

Received 30 January 1996; revised 26 April 1996; accepted 6 May 1996

\begin{abstract}
Objectives: To determine placental transfer of ketanserin and to assess the effect of serotonin-2 receptor blockade by ketanserin on serotonin- and phenylephrine-induced vasoconstriction. Study design: Five chronically instrumented pregnant ewes at 120 days gestation were injected with $20 \mathrm{mg}$ ketanserin i.v., and fetal and maternal arterial samples were obtained at predetermined intervals to assess placental transfer. Maternal and fetal responses of blood flows and pressures were determined after injection of serotonin $(20 \mu \mathrm{g} / \mathrm{kg})$ or phenylephrine $(10 \mu \mathrm{g} / \mathrm{kg})$ before and after ketanserin $(0.75 \mathrm{mg} / \mathrm{kg})$. Results: In the ewe, ketanserin is transferred across the placenta and reaches measurable levels in the fetal lamb. Ketanserin blocks the maternal and fetal serotonin-induced rise in arterial pressure, but not the serotonin-induced reduction in uterine blood flow. Conclusion: In the pregnant ewe,the serotonininduced rise in maternal and fetal blood pressure is effectively antagonized by ketanserin, whereas the serotonin-induced reduction in uterine blood flow is not.
\end{abstract}

Keywords: Serotonin; Ketanserin; Uterine blood flow; Pregnant ewe

\section{Introduction}

The circulation in untreated preeclamptic patients is characterized by an elevated blood pressure, reduced cardiac output, and an increased systemic vascular resistance with reduced perfusion of the placenta and maternal organs including the kidney [1]. There is increasing evidence that preeclampsia is a trophoblast-dependent pathophysiological process that starts early in pregnancy and is mediated by platelet activation, caused by damaged or dysfunctional endothelium leading to vasoconstriction [2,3].

Serotonin (5-hydroxytryptamine, 5-HT) is released following platelet aggregation and platelets are known to augment the effect of other vasoconstrictors through the release of serotonin [4]. Because platelet activation

* Corresponding author. Tel.: +31 10 4087596; fax: +31 104087532 ; e-mail: schneider@gyno.fgg.eur.nl. and aggregation are associated with release of serotonin, this vasoactive substance and its receptors may be involved in the pathophysiology of preeclampsia $[5,6]$.

The antihypertensive drug ketanserin (Ketensin ${ }^{\otimes}$ ) is a selective antagonist of serotonin receptors that belong to the 5-HT-2 category. Ketanserin lowers blood pressure through reduction of peripheral vascular resistance, while cardiac output remains virtually unaltered [7]. In addition to its antihypertensive effect, ketanserin also blocks the serotonin-induced aggregation of platelets [8]. From a theoretical point of view, these pharmacologic features make ketanserin an attractive choice for the antihypertensive treatment of patients with preeclampsia, and a number of small clinical studies have been published [9-13]. However, its potential use in pregnancy could be offset by unwanted side effects on the uteroplacental and fetal circulations, the latter depending on placental transfer and fetal sensitivity to the drug. There are limited experimental data in pregnant rats on the effects of ketanserin on maternal hemo- 
dynamics and uteroplacental circulation [14], and no information on placental transfer is available.

The present study was designed to determine in chronically instrumented pregnant ewes the placental transfer of ketanserin from the ewe to the fetal lamb, and to assess the effect of blockade of serotonin-2 receptors by ketanserin on serotonin- and phenylephrineinduced vasoconstriction.

\section{Materials and methods}

We studied five chronically instrumented pregnant Texel ewes with a median (range) weight of 62 (59-69) $\mathrm{kg}$ at 120 (115-135) days of gestation (term 145 days). Guidelines for the care and use of the animals, approved by the University Animal Experiments Committee, were followed.

\subsection{Surgical protocol}

The animals were acclimatized in the animal research facility for at least 3 days before operation. Twelve hours prior to surgery the animals were taken off food, but water remained freely available. After premedication with ketamine ( $15 \mathrm{mg} / \mathrm{kg}$ bodyweight) and atropine $(0.5 \mathrm{mg})$ i.m., anesthesia was induced with thiopentalsodium (7-14 mg/kg) i.v. The ewe was intubated and ventilated, anesthesia was maintained with enflurane $2 \%$ in a 2:1 mixture of nitrous oxide and oxygen. Through a lower abdominal midline incision and a small incision in the uterus, the fetal hindlimbs were exteriorized. Polyethylene catheters were introduced in both fetal femoral arteries and in one femoral vein and threaded into the distal aorta and vena cava, respectively. Fetal weight was estimated by palpation and the uterine incision was closed. A precalibrated electromagnetic flow probe, (IS10-S-A-0, Skalar, Delft, The Netherlands) of appropriate size (ID $2.5-4.5 \mathrm{~mm}$ ) was placed around the main uterine artery on the side of the instrumented fetal lamb, and a uterine vein was catheterized through a sidebranch. All catheters were tunnelled, exteriorized through a flank incision and secured in a pouch attached to the flank. A catheter was placed in a maternal carotid artery and vein through an incision in the neck. All catheters were flushed daily with a saline solution containing amoxicillin $(10 \mathrm{mg} / \mathrm{ml})$, metronidazole $(5 \mathrm{mg} / \mathrm{ml})$ and heparin $(100 \mathrm{U} / \mathrm{ml})$.

\subsection{Experimental protocol}

Experiments were performed after at least 2 days of recovery with the ewes standing quietly in an individual cage with unlimited access to food and water. Maternal and fetal arterial pressures were measured using Gould Statham P 23 ID pressure transducers. Pressures and uterine artery blood flow signals were recorded on a
Gould Brush 2800 recorder (Cleveland, USA), and stored on hard-disk with a sample frequency of $1 \mathrm{~Hz}$.

On the first experimental day we assessed placental transfer of ketanserin. After a 30-min control period, a 20-mg bolus of ketanserin was slowly injected into the maternal vein. Fetal and maternal arterial samples (1 ml) were obtained at 5, 30, 60, 120, 180, and $240 \mathrm{~min}$ after injection.

After immediate centrifugation, the plasma was stored at $-20^{\circ} \mathrm{C}$ until assay. Ketanserin concentrations were determined fluorometrically after high-performance liquid chromatography [15]. The minimum detectable concentration was $2.0 \mathrm{ng} / \mathrm{ml}$.

In a second experiment, the efficacy of blockade of serotonin-2 receptors and of $\alpha-1$-adrenoreceptors by ketanserin was investigated. On consecutive days we measured responses after injection of serotonin (20 $\mu \mathrm{g} / \mathrm{kg})$ or phenylephrine $(10 \mu \mathrm{g} / \mathrm{kg})$ into either a maternal or a fetal vein, both in the control state and $30 \mathrm{~min}$ after intravenous injection of a single dose of ketanserin $(0.75 \mathrm{mg} / \mathrm{kg}$ of maternal or estimated fetal weight). Before, during and after experiments maternal and fetal arterial samples $(1 \mathrm{ml})$ were drawn for immediate blood gas analysis (ABL 3, Radiometer, Copenhagen, Denmark) and determination of hemoglobin concentrations (OSM2, Radiometer, Copenhagen, Denmark) to verify maternal and fetal health throughout the experiment.

\subsection{Data analysis}

Ketanserin concentrations are presented as median values ( \pm ranges), all other variables as means ( \pm S.D.). We used Student's $t$-test for paired samples to assess differences between test periods. A $P$-value of $<0.05$ was taken as the level of significance.

\section{Results}

All ewes and fetal lambs remained in good condition during the week after surgery and throughout the experiments. Before the administration of ketanserin to the ewe or the fetal lamb median (range) values of maternal and fetal $\mathrm{pH}$ were $7.42(7.40-7.43)$ and 7.35 (7.33-7.38), respectively; after ketanserin values were similar, 7.41 (7.40-7.43) and 7.34 (7.30-7.35), respectively. Median (range) estimated fetal weight was $2500(1500-3500) \mathrm{g}$, not different from the median (range) birthweight of $2570(1850-3850) \mathrm{g}$.

\subsection{Placental transfer of ketanserin}

Maternal and fetal arterial plasma concentrations following injection of $20 \mathrm{mg}$ of ketanserin into a maternal vein are presented in Fig. 1. The median half-life of ketanserin in the arterial circulation of the ewe was 13 min. Five minutes after injection of ketanserin the medi- 


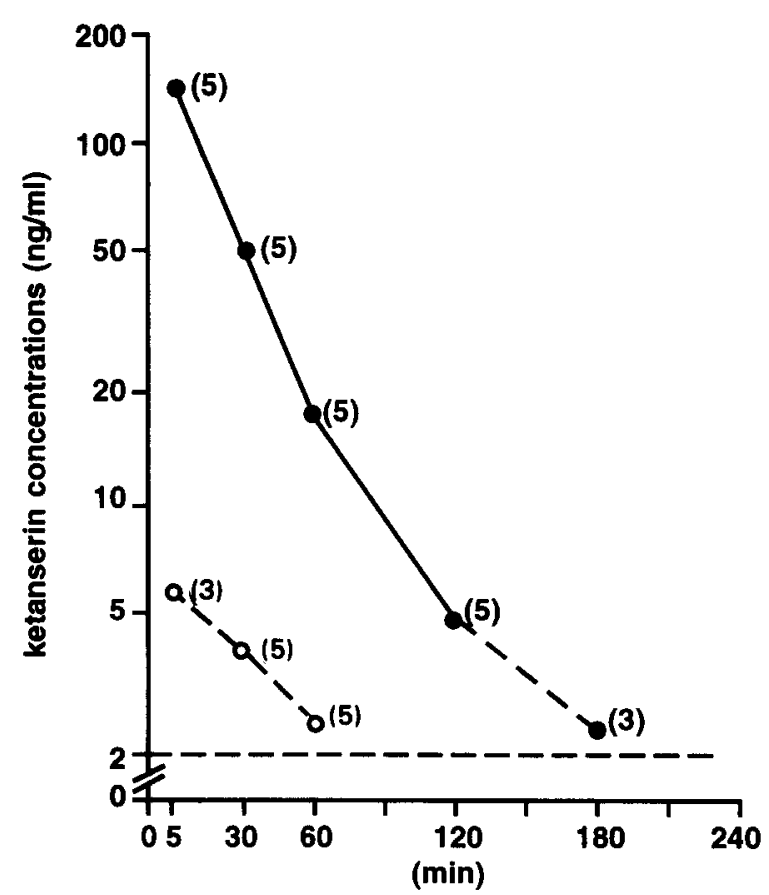

Fig. 1. Median concentrations of ketanserin $(\mathrm{ng} / \mathrm{ml})$ in maternal $(\Theta)$ and fetal $(\mathrm{O})$ arterial plasma following intravenous administration of $20 \mathrm{mg}$ ketanserin in five pregnant ewes. The minimal detectable concentration of ketanserin is indicated by the horizontal broken line. Numbers of samples with detectable levels between parentheses.

an maternal arterial concentration reached a peak value of $153 \mathrm{ng} / \mathrm{ml}$, with a wide range of $105-588 \mathrm{ng} / \mathrm{ml}$. Low median concentrations of $6.1 \mathrm{ng} / \mathrm{ml}$ (range $<2.0-25.4$ $\mathrm{ng} / \mathrm{ml}$ ) were demonstrated in three of five fetal lambs, whereas no ketanserin was detected in two fetuses. Thirty minutes after injection ketanserin was demonstrated in all five fetal lambs, with a median arterial concentration of $18 \%$ (range $3-85 \%$ ) of that in the ewe.

\subsection{Blockade of serotonin-2 receptors by ketanserin}

\subsubsection{Serotonin-2 blockade in the ewe}

Results are presented in Table 1A and Fig. 2. Intravenous administration of ketanserin to the ewe in a dose of $0.75 \mathrm{mg} / \mathrm{kg}$, was followed by a variable reduction in maternal arterial pressure by an average of $11 \%$ and an increase in uterine blood flow of approximately $13 \%$ $(P<0.05)$; the effect on fetal arterial pressure was negligible. In the absence of ketanserin, intravenous administration of serotonin $(20 \mu \mathrm{g} / \mathrm{kg})$ to the ewe was associated with a monophasic pressor response and caused a maximum increase in mean maternal arterial pressure of $48 \%$, a reduction in uterine blood flow of $81 \%$, and an increase in fetal arterial pressure of $32 \%$; all changes were highly significant $(P<0.001)$.

After intravenous administration of ketanserin, serotonin had hardly any effect on maternal arterial pressure, but uterine blood flow still fell by approximately $75 \%$ in all cases; the fall in uterine blood flow was similar to that observed after serotonin in the absence of ketanserin administration. Fetal arterial pressure showed a variable and non-significant increase of approximately $15 \%$.

\subsubsection{Serotonin-2 blockade in the fetal lamb}

Results are summarized in Table 1B. Intravenous in-

Table 1

Peak maternal and fetal hemodynamic responses to intravenous administration of serotonin $(20 \mu \mathrm{g} / \mathrm{kg})$ to the ewe (A) and to the fetal lamb (B), before and after ketanserin $(0.75 \mathrm{mg} / \mathrm{kg})(n=5)$

\begin{tabular}{|c|c|c|c|c|c|c|}
\hline & \multicolumn{3}{|c|}{ Before ketanserin } & \multicolumn{3}{|l|}{ After ketanserin } \\
\hline & Control values & $\begin{array}{l}\text { Changes after } \\
\text { serotonin }\end{array}$ & $P$-value & Control values & $\begin{array}{l}\text { Changes after } \\
\text { serotonin }\end{array}$ & $P$-value \\
\hline \multicolumn{7}{|l|}{$A$} \\
\hline $\begin{array}{l}\text { Maternal arterial pressure } \\
(\mathrm{mmH})\end{array}$ & $106 \pm 13$ & $+51 \pm 23$ & $<0.001$ & $94 \pm 9$ & $-7 \pm 19$ & n.s. \\
\hline $\begin{array}{l}\text { Uterine blood flow } \\
(\mathrm{ml} / \mathrm{min})\end{array}$ & $134 \pm 37$ & $-108 \pm 29$ & $<0.001$ & $151 \pm 43$ & $-110 \pm 44$ & $<0.001$ \\
\hline $\begin{array}{l}\text { Fetal arterial pressure } \\
(\mathbf{m m H g})\end{array}$ & $65 \pm 7$ & $+21 \pm 7$ & $<0.001$ & $59 \pm 8$ & $+9 \pm 14$ & n.s. \\
\hline \multicolumn{7}{|l|}{$B$} \\
\hline $\begin{array}{l}\text { Maternal arterial pressure } \\
(\mathrm{mmH})\end{array}$ & $99 \pm 10$ & $+8 \pm 9$ & n.s. & $101 \pm 9$ & $+16 \pm 21$ & n.s. \\
\hline $\begin{array}{l}\text { Uterine blood flow } \\
(\mathrm{ml} / \mathrm{min})\end{array}$ & $166 \pm 29$ & $+8 \pm 21$ & n.s. & $189 \pm 16$ & $-16 \pm 19$ & n.s. \\
\hline $\begin{array}{l}\text { Fetal arterial pressure } \\
(\mathrm{mmHg})\end{array}$ & $63 \pm 10$ & $+20 \pm 8$ & $<0.05$ & $62 \pm 11$ & $+7 \pm 6$ & n.s. \\
\hline
\end{tabular}

Values are means \pm S.D. n.s., not significant $(P>0.05)$. 

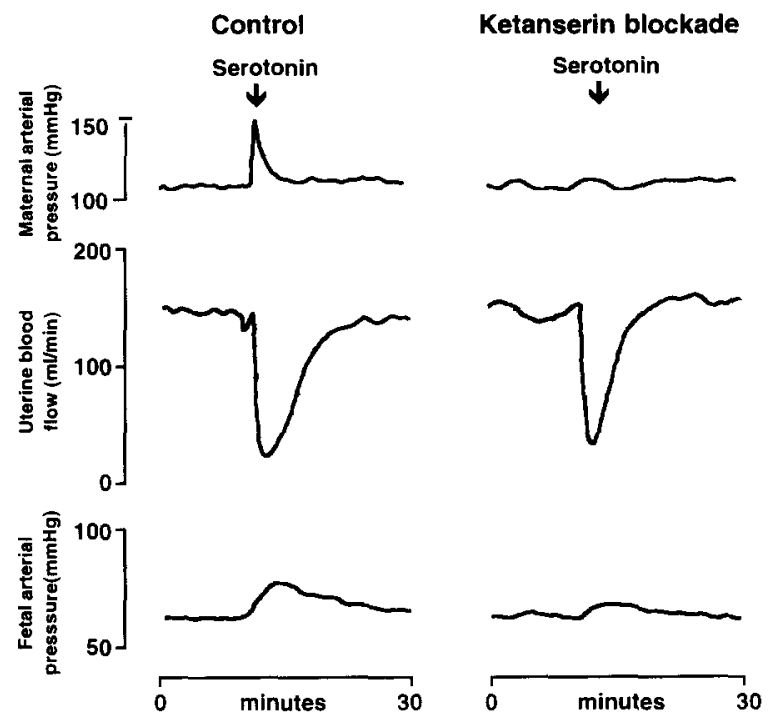

Fig. 2. Circulatory changes induced by i.v. injection of $20 \mu \mathrm{g} / \mathrm{kg}$ serotonin into a single ewe before and after ketanserin blockade.

jection of serotonin $(20 \mu \mathrm{g} / \mathrm{kg})$ into the fetal lamb caused a significant rise in fetal arterial pressure of $32 \%$. The small changes observed in maternal arterial pressure and in uterine blood flow were variable and not statistically significant.

After administration of ketanserin, serotonin caused a small and non-significant increase in fetal arterial pres-

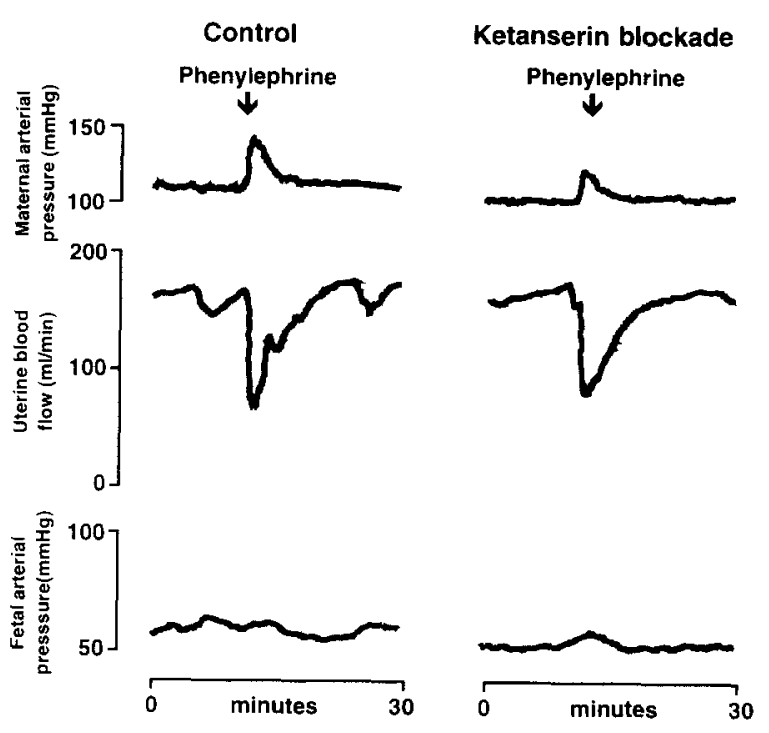

Fig. 3. Circulatory changes induced by i.v. injection of $10 \mu \mathrm{g} / \mathrm{kg}$ phenylephrine into a single ewe before and after ketanserin blockade.

sure (11\%); maternal arterial pressure and uterine blood flow were not significantly affected.

\subsection{Blockade of $\alpha$-1-adrenergic receptors by ketanserin}

\subsubsection{Alpha-1-adrenergic blockade in the ewe}

Results are presented in Table 2A and Fig. 3. Intra-

Table 2

Peak maternal and fetal hemodynamic responses to intravenous administration of phenylephrine $(10 \mu \mathrm{g} / \mathrm{kg})$ to the ewe (A) and to the fetal lamb (B), before and after ketanserin $(0.75 \mathrm{mg} / \mathrm{kg})(n=5)$

\begin{tabular}{|c|c|c|c|c|c|c|}
\hline & \multicolumn{3}{|c|}{ Before ketanserin } & \multicolumn{3}{|l|}{ After ketanserin } \\
\hline & Control values & $\begin{array}{l}\text { Changes after } \\
\text { phenylephrine }\end{array}$ & $P$-value & Control values & $\begin{array}{l}\text { Changes after } \\
\text { phenylephrine }\end{array}$ & $P$-value \\
\hline \multicolumn{7}{|l|}{$A$} \\
\hline $\begin{array}{l}\text { Maternal arterial pressure } \\
\quad(\mathrm{mmH})\end{array}$ & $108 \pm 1$ & $+38 \pm 16$ & 0.005 & $92 \pm 17$ & $+29 \pm 8$ & 0.001 \\
\hline $\begin{array}{l}\text { Uterine blood flow } \\
(\mathrm{ml} / \mathrm{min})\end{array}$ & $156 \pm 13$ & $-65 \pm 53$ & 0.01 & $163 \pm 13$ & $-75 \pm 25$ & 0.002 \\
\hline $\begin{array}{l}\text { Fetal arterial pressure } \\
\quad(\mathrm{mmHg})\end{array}$ & $67 \pm 9$ & $+5 \pm 3$ & n.s. & $54 \pm 12$ & $+8 \pm 6$ & n.s. \\
\hline \multicolumn{7}{|l|}{$B$} \\
\hline $\begin{array}{l}\text { Maternal arterial pressure } \\
(\mathrm{mmHg})\end{array}$ & $104 \pm 8$ & $+7 \pm 10$ & n.s. & $104 \pm 9$ & $0 \pm 4$ & n.s. \\
\hline $\begin{array}{l}\text { Uterine blood flow } \\
(\mathrm{ml} / \mathrm{min})\end{array}$ & $183 \pm 40$ & $-36 \pm 15$ & 0.02 & $186 \pm 20$ & $-10 \pm 19$ & n.s. \\
\hline $\begin{array}{l}\text { Fetal arterial pressure } \\
\quad(\mathrm{mmHg})\end{array}$ & $67 \pm 10$ & $+21 \pm 10$ & 0.001 & $67 \pm 10$ & $+7 \pm 5$ & n.s. \\
\hline
\end{tabular}

n.s., not significant $(P>0.05)$. 
venous administration of phenylephrine significantly increased maternal arterial pressure by $35 \%$, and reduced uterine blood flow by $41 \%$; fetal arterial pressure showed a small and variable rise. Similar responses to phenylephrine were observed following ketanserin administration.

\subsubsection{Alpha-1-adrenergic blockade in the fetal lamb}

Results are presented in Table 2B. Phenylephrine injection into the fetal lamb induced a significant increase in fetal arterial pressure of approximately $31 \%$. Maternal arterial blood pressure did not change significantly, but uterine blood flow showed a significant fall of $20 \%$. After ketanserin injection into the fetal lamb, phenylephrine did not significantly affect fetal and maternal arterial pressures or uterine blood flow.

\section{Discussion}

In our experiments in the pregnant ewe, ketanserin appeared to be transferred across the placenta. Fetal ketanserin levels were low, with marked variability, indicating limited transfer with a large inter-individual variation. The disappearance of ketanserin from maternal plasma in our sheep experiments, as judged from the median half-life of $13 \mathrm{~min}$, was similar to that observed in non-pregnant humans [16]. Intravenous administration of ketanserin in a single dose of $0.75 \mathrm{mg} / \mathrm{kg}$ resulted in a small fall in maternal arterial pressure associated with a small increase in uterine arterial flow. Although these changes were statistically significant, they were variable and should be interpreted with care. We used normotensive ewes and maternal hemodynamic responses in conditions of hypertension could be different. Maternal or fetal administration of ketanserin was not associated with changes in fetal hemodynamics. Maternal and fetal arterial blood gas samples showed normal values after ketanserin administration to the ewe or the fetus. These results indicate that ketanserin in the single dose investigated has no deleterious effects on fetal condition.

We found that serotonin injection in the pregnant ewe was associated with a monophasic arterial pressor response, vasoconstriction of the uterine artery with a fall in uterine blood flow, and a rise in fetal arterial pressure.

Our observations are in agreement with those by Lang et al. [17], also in pregnant sheep, but contrary to the findings of van Zwieten et al. [6], who observed a triphasic response to intravenous injection of serotonin in rats and other experimental animals. After blockade of the 5-HT-2-receptors with ketanserin, the arterial pressor response to serotonin in the ewe and in the fetal lamb was completely inhibited while uterine blood flow decreased as before. Previous studies showed that constriction of the uterine vasculature induced by $2,5-$ dimethoxy-4-methylamphetamine (DOM), a highly selective 5-HT-2 agonist, can be completely inhibited by ketanserin $[18,19]$. The observation that in our experiments ketanserin did not modulate the uterine vascular response to serotonin suggests that in pregnancy, in addition to 5-HT-2 receptors, other receptors could be involved in the vasoconstrictor response of the ovine uterine artery to exogenous serotonin.

Phenylephrine, a vasoconstrictor of sustained action mainly mediated by $\alpha$-receptors, administered to the ewe increased maternal arterial pressure and reduced uterine blood flow. In our experiments ketanserin, in the relatively low dose of $0.75 \mathrm{mg} / \mathrm{kg}$, did not inhibit the phenylephrine-induced pressor response in the ewe. In contrast, ketanserin in a much higher dose of $10 \mathrm{mg} / \mathrm{kg}$, as used by Nelson et al. [20], did show a significant $\alpha$ blocking effect in sheep. In the fetal lamb, however, ketanserin clearly showed $\alpha$-antagonist activity by blocking the rise in fetal arterial pressure induced by phenylephrine.

Phenylephrine administered to the fetal lamb not only caused a rise in fetal arterial pressure, but also a variable but significant fall in uterine blood flow. This was an unexpected observation, for which we cannot present a logical explanation. The dose of $10 \mu \mathrm{g} / \mathrm{kg}$ of estimated fetal weight appears too low to cause an effective concentration in the maternal circulation after placental transfer and, indeed, no changes in maternal blood pressure were apparent.

In conclusion, our animal experiments have shown that ketanserin may prevent the serotonin-induced rise in maternal blood pressure, without an effect on a serotonin-induced reduction in uterine blood flow. If we assume that serotonin contributes to the maternal vasoconstriction that is characteristic of hypertensive pregnancy [5], and if we extrapolate our findings in the pregnant ewe to the preeclamptic patient, our results suggest that ketanserin may reduce maternal hypertension without an effect on uterine blood flow.

\section{References}

[1] Visser W, Wallenburg HCS. Central hemodynamic observations in untreated preeclamptic patients. Hypertension 1991; 17 : 1072-1077.

[2] Wallenburg HCS, Rotmans P. Enhanced reactivity of the platelet thromboxane pathway in normotensive and hypertensive pregnancies with insufficient growth. Am J Obstet Gynecol 1982; 144: 523-528.

[3] Redman CWG. Platelets and the beginning of preeclampsia. N Engl J Med 1990; 323: 478-480.

[4] Weyrich AS, Solis GA, Li KS, Tulenko TN, Santamore WP Platelet amplification of vasospasm. Am J Physiol 1992; 263: 349-358.

[5] Weiner CP. The role of serotonin in the preeclampsia eclampsiasyndrome. Cardiovasc Drugs Ther 1990; 4: 37-43.

[6] van Zwieten PA, Blauw GJ, van Brummelen P. Serotonergic receptors and drugs in hypertension. Pharmacol Toxicol 1992; 70: $\mathrm{S} 17-\mathrm{S} 22$. 
[7] Wenting GJ, Man in't Veld AJ, Woittiez AJJ, Boomsma F, Schalekamp MADH. Treatment of hypertension with ketanserin, a new selective 5-HT-2 receptor agonist. Br Med J 1982; 284: 537-539.

[8] De Clerck F, David JL, Janssen PAJ. Inhibition of 5hydroxytryptamine-induced and -amplified human platelet aggregation by ketanserin (R41486), a selective 5-HT-2-receptor antagonist. Agents Actions 1982; 12: 388-397.

[9] Weiner CP, Socol ML, Vaisrub N. Control of preeclamptic hypertension by ketanserin, a new serotonin receptor antagonist. Am J Obstet Gynecol 1984; 149: 496-500.

[10] Montenegro R, Knuppel RA, Shah D, O'Brien WF. The effect of serotonergic blockade in postpartum preeclamptic patients. Am J Obstet Gynecol 1985; 153: 130-134.

[11] Hulme VA, Odendaal HJ. Intrapartum treatment of preeclamptic hypertension by ketanserin. Am J Obstet Gynecol 1986; 155 : 260-263.

[12] Voto LS, Zin C, Neira J, Lapidus AM, Margulies M. Ketanserin versus $\alpha$-methyldopa in the treatment of hypertension during pregnancy: a preliminary report. J Cardiovasc Pharmacol 1987; 10: S101-S103.

[13] Rossouw HJ, Howarth G, Odendaal HJ. Ketanserin and hydralazine in hypertension in pregnancy - a randomized double-blind trial. S Afr Med J 1995; 85: 525-528.

[14] Furuhashi N, Tsujiei M, Kimura H, Yajima A. Effects of ketanserin - a serotonin receptor antagonist - on placental blood flow, placental weight and fetal weight of spontaneously hypertensive rats and normal wistar kyoto rats. Gynecol Obstet Invest 1991; 32: 65-67.

[15] Okonkwo PO, Reimann IW, Woestenborghs R. High performance liquid chromatographic assay with fluorometric detection of ketanserin, a new antihypertensive agent and serotonin S-2 antagonist in human plasma, blood and urine. J Chromatogr 1983; 272: 411-416.

[16] Heykants J, van Peer A, Woestenborghs R, Gould S, Mills J. Pharmacokinetics of ketanserin and its metabolite ketanserin-ol in man after intravenous, intramuscular and oral administration. Eur J Clin Pharmacol 1986; 31: 343-350.

[17] Lang U, Prada J, Clark KE. Systemic and uterine vascular response to serotonin in third trimester pregnant ewes. Eur $\mathrm{J}$ Obstet Gynecol Reprod Biol 1993; 51: 131-138.

[18] Zhang L, Dyer DC. Characterization of 5-hydroxytryptamine receptors on isolated ovine uterine artery in late pregnancy. $J$ Pharmacol Exp Ther 1990; 253: 1236-1244.

[19] Zhang L, Dyer DC, Hembrough FB, Isla M. Effect of R(-)2,5dimethoxy-4-methylamphetamine on uterine and umbilical blood flow in conscious pregnant sheep. Eur J Pharmacol 1991; 199: 179-184.

[20] Nelson MA, Coghlan JP, Denton DA et al. Demonstration of $\alpha$-adrenoreceptor antagonism by the 5-HT-2 antagonist ketanserin (R49945) in sheep. Clin Exp Pharmacol Physiol 1984; 11: 597-604. 